\title{
PERSEPSI MAHASISWA TERHADAP PEMBELAJARAN DARING MATA KULIAH MIKROBIOLOGI
}

\author{
Ermina Sari ${ }^{1)}$, Lufri $^{2)}$, Andromeda ${ }^{3)}$, Fatni Mufit ${ }^{4)}$ \\ ${ }^{1}$ Jurusan Pendidikan Biologi, Universitas Lancang Kuning \\ ${ }^{2,3,4}$ Jurusan Pendidikan IPA, Universitas Negeri Padang \\ Email $^{1)}$ :ermina@unilak.ac.id
}

\begin{abstract}
ABSTRAK: Pandemi Covid-19 telah merubah cara kerja masyarakat, termasuk dalam hal pendidikan dan pengajaran. Untuk mencegah meningkatnya kasus Covid19 ini, Menteri Pendidikan dan Kebudayaan telah mengeluarkan kebijakan tentang proses belajar mengajar yang dilakukan secara online. Tujuan dari penelitian ini adalah untuk mengevaluasi persepsi mahasiswa tentang pembelajaran online selama pandemi Covid-19 pada matakuliah mikrobiologi dasar dan mikrobiologi analitik. Penelitian ini menggunakan metode analisis deskriptif kuantitatif dengan instrumen penelitian berupa kuesioner yang disebar secara online dengan bantuan google form. Jumlah sampel pada penelitian ini sebanyak 69 mahasiswa dari program studi pendidikan Biologi, Universitas Lancang Kuning yang terlibat dalam pembelajaran daring selama pandemic Covid-19. Hasil penelitian menunjukkan $50.72 \%$ mahasiswa menyatakan bahwa perkuliahan daring memudahkan dalam memahami materi, meningkatkan motivasi belajar $62.32 \%$, membantu dalam belajar $75.36 \%$ dan membantu dalam kesiapan perkuliahan sebesar $75.36 \%$. Tingkat persepsi terhadap aspek pelaksanaan proses belajar mengajar, kompetensi dosen dan sarana prasarana menunjukkan persepsi positif dengan tingkat persepsi berturut-turut sebesar $74.55 \%$, $80.87 \%$ dan $77.83 \%$. Secara keseluruhan sebanyak $84.04 \%$ mahasiswa puas dengan perkuliahan daring khususnya pada matakuliah Mikrobiologi.
\end{abstract}

Kata kunci : Persepi, daring, mikrobiologi.

ABSTRACT: The Covid-19 pandemic has changed the way people work, including in the field of education. To prevent the increase in cases of Covid-19, the Minister of Education and Culture has issued a policy regarding the online teaching and learning process. The aim of this study was to evaluate students' perceptions of online learning during the Covid-19 pandemic in basic microbiology and analytical microbiology subjects. This study uses a quantitative descriptive analysis method with a research instrument in the form of a questionnaire distributed online with the help of google form. The number of samples in this study were 69 students from the Biology education study program, Lancang Kuning University, who were involved in online learning during the Covid-19 pandemic. The results showed that 50.72\% of students stated that online lectures made it easier to understand the material, increased learning motivation $62.32 \%$, helped in learning $75.36 \%$ and helped in lecture readiness by $75.36 \%$. The level of perception of the aspects of the teaching and learning process, capabilities (competence of lecturers) and infrastructure shows

Bio-Lectura: Jurnal Pendidikan Biologi, Vol 8, No 2,Oktober 2021 
a positive perception with perceptual levels of $74.55 \%, 80.87 \%$ and $77.83 \%$ respectively. Overall, as many as $84.04 \%$ of students were satisfied with online lectures, especially in the Microbiology course.

Keywords : Perception, online, Microbiology

\section{PENDAHULUAN}

Corona Virus Disease 2019 (Covid 19) pertama kali muncul pada akhir tahun 2019 di Wuhan. Covid 19 merupakan virus yang penularannya sulit dikendalikan dan sangat cepat. Untuk memprediksi penyebaran Covid 19, semua negara mengalami efek Covid 19 dan melakukan lockdown. Berbagai sektor lumpuh, awalnya sektor ekonomi, namun sektor pendidikan lumpuh dengan semakin ganasnya Covid-19 dan SWH (School From Home) diadopsi oleh hampir semua sekolah di berbagai negara.

Pandemi Covid-19 yang memungkinkan pendidik dan peserta didik melakukan kegiatan perkuliahan dari rumah menjadikan metode pembelajaran jarak jauh sebagai pemecahan dari permasalahan pembelajaran. Pendidikan jarak jauh merupakan proses pembelajaran di mana peserta didik terpisah dari pendidik dan pengajarannya dilakukan menggunakan alat belajar yang berbeda diantaranya melalui teknologi komunikasi, informasi dan media lainnya. Pembelajaran daring adalah proses pendidikantanpa tatap muka dan memakai platform tertentu sehingga dapat dilakukan dari jarak jauh. Pembelajaran daring bertujuan untuk memberikan jaringan dan layanan pembelajaran yang lebih luas (Sofyana \& Abdul, 2019: 82). Whatsapp, zoom, google classroom, google meet, web blog, edmodo dan lain-lain adalah aplikasi yang dapat digunakan untuk kegiatan belajar mengajar jarak jauh.
Pembelajaran daring memiliki tantangan bagi pendidik dan peserta didik dalam penggunaan keahlian teknologi informasi.

Salah satu mata kuliah yang terkena dampak Covid-19 dan dilakukan secara daring di program studi pendidikan Biologi adalah mata kuliah mikrobiologi. Perkuliahan mikrobiologi ini idealnya dilakukan secara luring, namun karena Covid-19 mengharuskan perkuliahan dilakukan secara daring. Hal ini menjadi tantangan baik bagi pendidik maupun peserta didik untuk dapat mengoptimalkan segala kondisi sehingga mampu melaksanakan perkuliahan daring secara baik. Perkuliahan secara daring dengan segala keterbatasan yang dimiliki pendidik dan peserta didik tentu akan mempengaruhi pemahaman peserta didik terhadap materi yang diberikan terutama pada mata kuliah mikrobiologi. Berawal dari persoalan ini, maka peneliti tertarik untuk mengetahui persepsi peserta didik dalam hal ini mahasiswa program studi pendidikan Biologi, Universitas Lancang Kuning terhadap pembelajaran daring pada mata kuliah mikrobiologi.

Beberapa penelitian relevan yang dilakukan terkait persepsi mahasiswa dalam pembelajaran daring adalah Ratnawati dan Vivianti (2020) yang menyatakan bahwa nilai persepsi mahasiswa dalam perkuliahan praktikum secara daring di Universitas Teknologi Yogyakarta termasuk kategori positif dengan tingkat persepsi $80 \%$. Selain itu penelitian lain menyimpulkan bahwa 
mahasiswa memiliki sarana dasar dalam mengikuti pembelajaran dan pembelajaran daring meningkatkan prilaku kemandirian mahasiswa dalam belajar (Sadikin dan Hamidah 2020).

Zhafira et al., (2020) dalam penelitiannya menyimpulkan media pembelajaran daring yang sangat disukai yaitu whatsapp dan Google Classroom. Sebanyak 53\% mahasiswa Fakultas Ekonomi Universitas Teuku Umar sudah mengetahui berbagai media pembelajaran daring tersebut sebelum perkuliahan dimulai. Pola komunikasi yang sangat disukai oleh mahasiswa yaitu pola semi dua arah. Hadi (2020) menyimpulkan bahwa mahasiswa sangat meminati pembelajaran luring daripada daring. Mahasiswa merasa pembelajaran daring menyulitkan karena sulitnya akses internet serta sulitnya mencari bahan belajar. Terkait hal ini, sangat dirasakan pentingnya keikutsertaan orang tua dalam mendampingi mahasiswa mengikuti pembelajaran.

Berbagai hasil penelitian terdahulu dengan kesimpulan yang berbeda menjadikan peneliti tertarik untuk melakukan penelitian mengenai persepsi mahasiswa terhadap pembelajaran daring. Artikel ini bertujuan untuk menganalisis persepsi mahasiswa dalam mengikuti perkuliahan mikrobiologi secara daring.

\section{METODE PENELITIAN}

Metode yang digunakan dalam penelitian ini adalah deskriptif kuantitatif. Metode Deskriptif adalah metode yang digunakan untuk menganalisis data dengan cara mendeskripsikan atau menggambarkan data yang telah terkumpul sebagaimana adanya tanpa bermaksud membuat kesimpulan yang berlaku untuk umum atau generalisasi (Sugiyono, 2013). Metode kuantitatif adalah metode untuk menguji teoriteori tertentu dengan cara meneliti hubungan antar variabel. Variabel-variabel ini diukur (biasanya dengan instrumen penelitian) sehingga data yang terdiri dari angka-angka dapat dianalisis berdasarkan prosedur statistik (Sugiyono, 2013).

Populasi penelitian adalah seluruh mahasiswa program studi Pendidikan Biologi, Universitas Lancang Kuning yang mengambil matakuliah Mikrobiologi Tahun Ajaran 2020/2021 yang berjumlah 79 mahasiswa yang berasal dari 3 kelas. Sampel penelitian berjumlah 69 mahasiswa yang diambil dengan teknik purposive sampling dengan pertimbangan 10 mahasiswa tidak dapat mengakses kuesioner yang disebar secara online melalui google form.

Pengumpulan data penilaian persepsi menggunakan metode kuesioner dengan mengadaptasi kuesioner penelitian persepsi yang dilakukan oleh Maulana dan Hamidi (2020). Angket terdiri dari 20 pernyataan yang terbagi atas 5 pernyataan proses pembelajaran, 6 pernyataan kapabilitas (kemampuan dosen), 2 pernyataan sarana prasarana. 7 pernyataan lagi mengenai survey durasi penggunaan internet dalam sehari, aplikasi yang biasa digunakan dalam pembelajaran daring, 4 manfaat yang dirasakan dalam pembelajaran daring, serta pernyataan kepuasan secara keseluruhan terhadap perkuliahan daring pada matakuliah mikrobiologi.

Teknik analisis data dilakukan dengan memberikan skor berdasarkan skala likert terhadap jawaban responden dengan kriteria sangat setuju (5), setuju (4), biasa saja (3), tidak setuju (2) dan sangat tidak setuju (1). Tingkat persepsi

Bio-Lectura: Jurnal Pendidikan Biologi, Vol 8, No 2,Oktober 2021 
mahasiswa dalam penelitian ini mengacu pada standar pengukuran persentase skor yaitu: Negatif jika persentase rerata total butir komponen $\leq$ $40 \%$, dan positif jika persentase rerata total butir komponen $>40 \%$.

\section{HASIL DAN PEMBAHASAN}

Berdasarkan hasil kuesioner yang disebar terhadap 69 mahasiswa mengenai penggunaan media/aplikasi disajikan pada Gambar 1. Hasilnya diperoleh data bahwa $98.55 \%$ pernah menggunakan whatsapp sebagai media pembelajaran daring, $66.67 \%$ menggunakan zoom meeting, $60.87 \%$ menggunakan email, $53.62 \%$ menggunakan google meet, $20.29 \%$ menggunakan google classroom dan 2,90\% menggunakan aplikasi Edmodo.

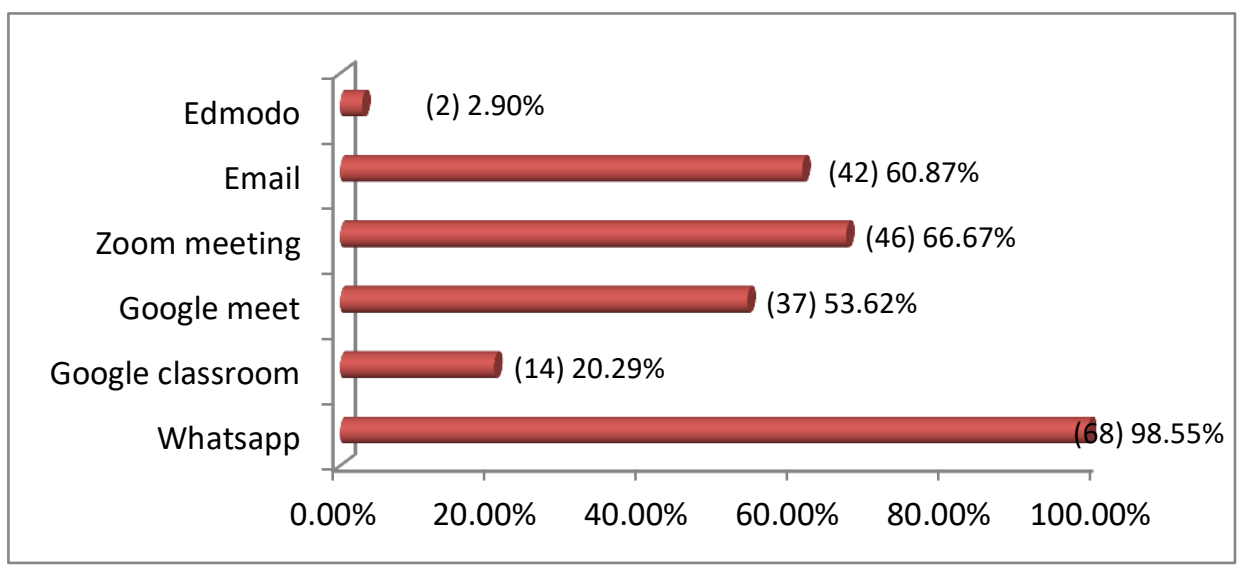

Gambar 1. Media/Aplikasi yang Biasa digunakan dalam Pembelajaran Daring

Durasi penggunaan internet perhari untuk pembelajaran setiap mahasiswa berbeda-beda. Berdasarkan Gambar 2, terlihat bahwa $33.33 \%$ mahasiswa menghabiskan 3-4 jam perhari, diikuti sebesar $18.84 \%$ mahasiswa menghabiskan 5-6 jam perhari, $17.39 \%$ menghabiskan 7-8 jam perhari, $13.04 \%$ menghabiskan 12 jam perhari, $11.59 \%$ menghabiskan 11-12 jam perhari dan hanya $5.80 \%$ menghabiskan 9-10 jam perhari untuk pembelajaran.

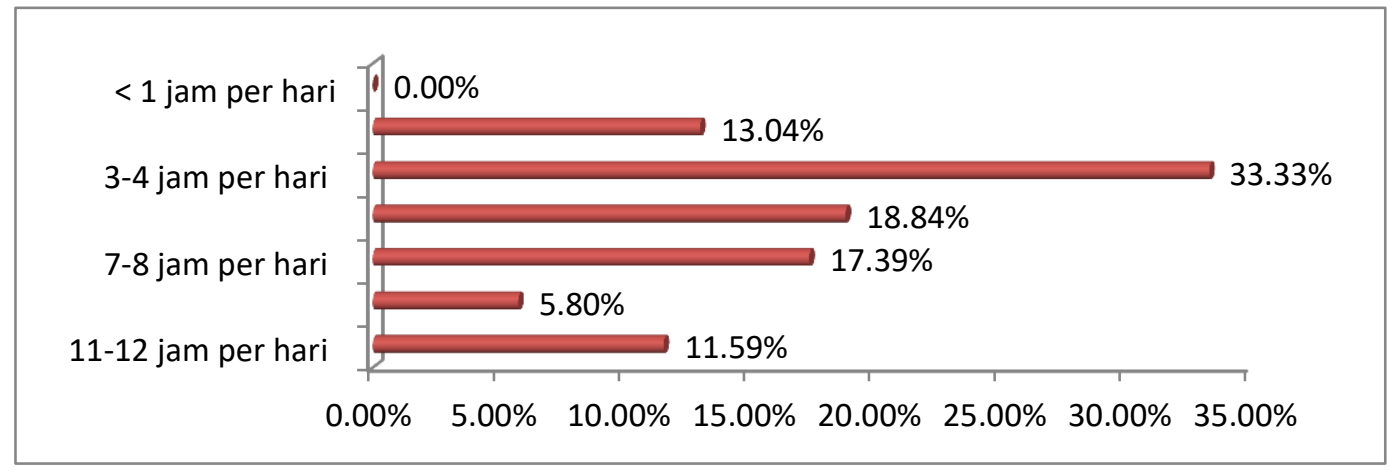

Gambar 2. Durasi Penggunaan Internet untuk Pembelajaran Perhari 
Secara keseluruhan untuk komponen aspek pelaksanaan PBM diperoleh persentase tingkat persepsi mahasiswa sebesar $74.55 \%$. Sementara untuk aspek kompetensi dosen diperoleh persentase tingkat persepsi mahasiswa sebesar $80.87 \%$, dan persentasi untuk aspek sarana prasarana tingkat persepsi mahasiswa sebesar $77.83 \%$. Hal ini menunjukkan bahwa mahasiswa program studi pendidikan Biologi menunjukkan persepsi yang positif terhadap pelaksanaan PBM, kompetensi dosen dan sarana prasarana yang dilakukan secara daring pada matakuliah mikrobiologi.

Manfaat yang dirasakan mahasiswa dalam perkuliahan daring pada mata kuliah mikrobiologi disajikan pada Gambar 3 dan 4. Sebanyak 50.72\% mahasiswa menyatakan bahwa pembelajaran mikrobiologi secara daring dapat memudahkan memahami materi pelajaran dan $62.32 \%$ mahasiswa menyatakan kuliah mikrobiologi secara daring dapat meningkatkan motivasibelajar.

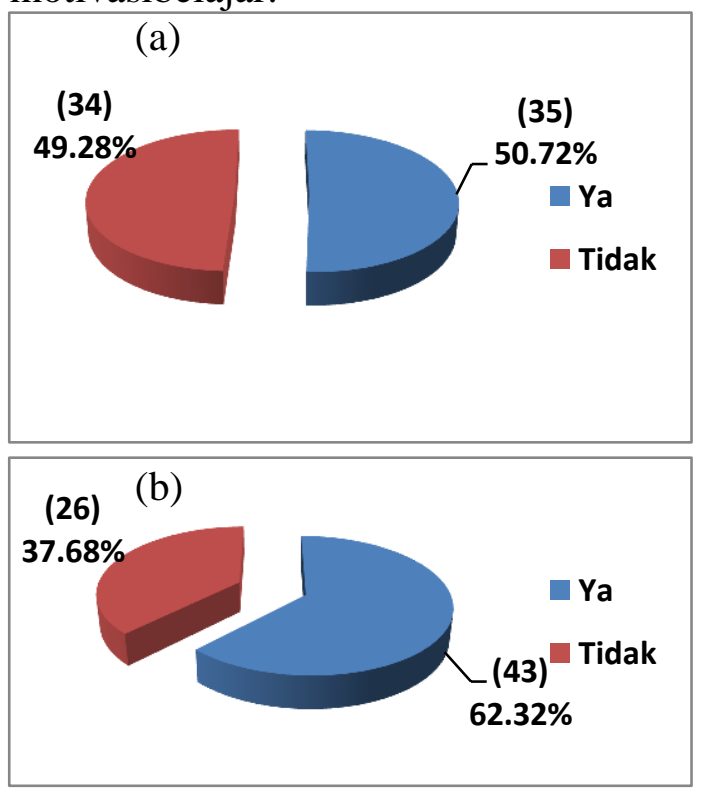

Gambar 3. (a) Kuliah Daring Memudahkan Memahami Materi Pelajaran (b) Kuliah Daring dapat meningkatkan Motivasi Belajar

Kuliah daring menurut $75.36 \%$ mahasiswa dapat membantu dalam belajar mikrobiologi dan $81.16 \%$ mahasiswa menyatakan bahwa kuliah mikrobiologi secara daring dapat membantu dalam kesiapan pembelajaran.
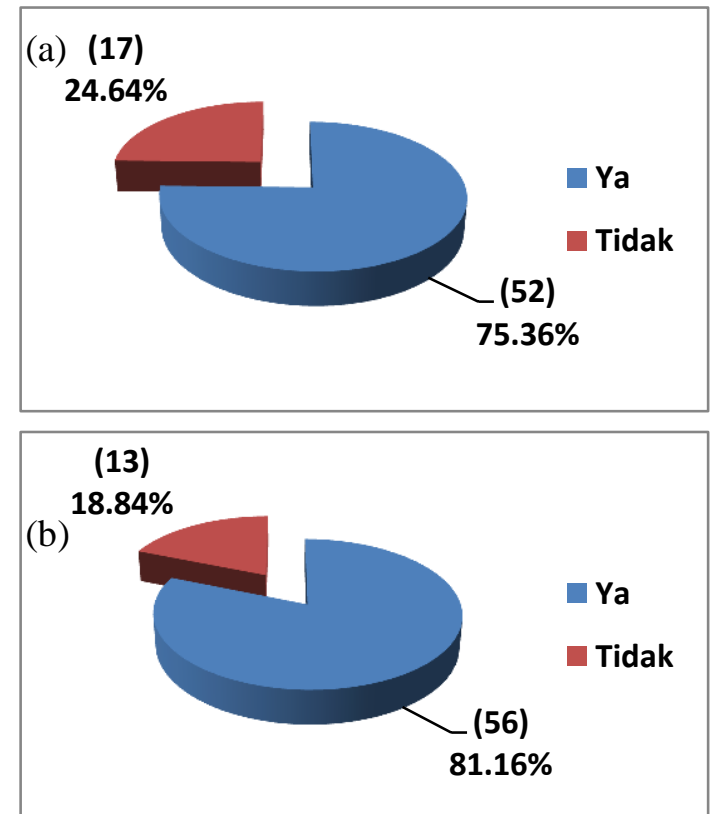

Gambar 4. (a) Kuliah Daring dapat Membantu dalam Belajar, (b) Kuliah Daring Membantu Kesiapan Perkuliahan Secara keseluruhan berdasarkan data angket yang diperoleh, tingkat kepuasan mahasiswa terhadap perkuliahan mikrobiologi yang dilakukan secara daring dinilai cukup positif. Terbukti bahwa sebanyak 58 mahasiswa dari 69 responden menyatakan bahwa mereka puas terhadap perkuliahan secara daring pada mata kuliah mikrobiologi (Gambar 5). Dapat dikatakan secara keseluruhan, tingkat persepsi mahasiswa adalah positif terhadap perkuliahan mikrobiologi secara daring. 


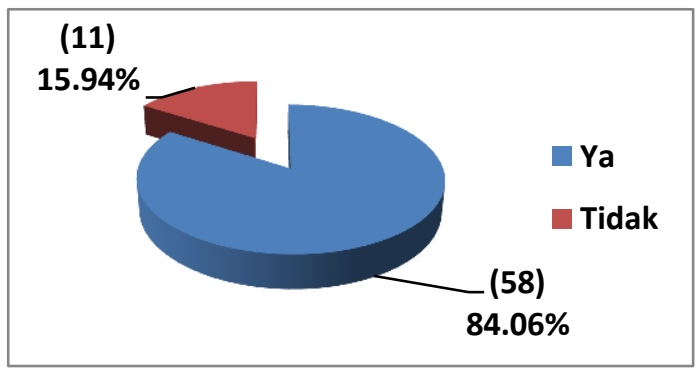

Gambar 5. Kepuasan Mahasiswa terhadap Perkuliahan daring pada Matakuliah Mikrobiologi

Kegiatan belajar mengajar online yang baik harus dapat diakses secara mudah dan diharapkan dilaksanakan tepat waktu dan sesuai dengan jadwal yang telah ditentukan. Materi yang disajikan juga harus di disain sedemikian rupa agar tujuan pembelajaran tercapai sesuai indikator yang telah disusun (Inah, 2015). Dari hasil angket diketahui bahwa terdapat $1.45 \%$ mahasiswa yang menyatakan bahwa materi yang diberikan tidak sesuai dengan RPS. Hal ini menunjukkan bahwa walaupun pembelajaran dilakukan secara online tetapi dosen tetap melaksanakan perkuliahan sesuai dengan RPS yang telah disampaikan pada pertemuan pertama.

Dalam peningkatan mutu, relevansi dan efisiensi dosen memegang peranan penting dan harus mampu mempersiapkan diri dengan kompetensi yang dimiliki secara optimal (Kadir, 2018). Kapabilitas dosen yang baik diharapkan mampu memberikan kemudahan mahasiswa dalam memahami materi perkuliahan yang diberikan.

\section{KESIMPULAN}

Pembelajaran daring pada mata kuliah Mikrobiologi di Universitas Lancang Kuning pada program studi pendidikan Biologi mendapat persepsi positif dari mahasiwa terhadap kepuasannya mengikuti perkuliahan dengan tingkat persepsi sebesar $84.06 \%$. Tingkat persepsi terhadap aspek proses belajar mengajar, kapabilitas (kompetensi dosen) dan sarana prasarana menunjukkan persepsi positif dengan tingkat persepsi berturut-turut sebesar $74.55 \%, 80.87 \%$ dan $77.83 \%$.

\section{DAFTAR PUSTAKA}

Hadi, L. 2020. Persepsi Mahasiswa Terhadap Pembelajaran Daring Di Masa Pandemik Covid-19. Jurnal Zarah, $8: 2(56-61)$.

Maulana, H. A. dan Hamidi, M. 2020. Persepsi Mahasiswa terhadap Pembelajaran Daring pada Mata Kuliah Praktik di Pendidikan Vokasi. Jurnal Equilibrium: Jurnal Pendidikan. VIII. 2, 224231.

Inah, E. N. (2015). Peran Komunikasi dalam Interaksi Guru dan Siswa. Jurnal Al-Ta'dib, 8(2), 150-167.

Kadir, A. (2018). Pengaruh Kompetensi Dosen dan Motivasi Belajar Terhadap Kemampuan Analisis Statistika Mahasiswa FTIK IAIN Kendari. Al Izzah: Jurnal HasilHasil Penelitian, 1(1), 1-15.

Ratnawati, D. dan Vivianti. 2020. PERSEPSI MAHASISWA TERHADAP PEMBELAJARAN DARING PADA MATA KULIAH PRAKTIK APLIKASI TEKNOLOGI INFORMASI. 
Jurnal Edukasi Elektro. 4 (2), 110 119.

Sadikin, A. dan Hamidah, A. 2020. Pembelajaran Daring di Tengah Wabah Covid-19. Jurnal Ilmiah Pendidikan Biologi. 6 (02) 214224.

Sofyana \& Abdul. 2019. Pembelajaran Daring Kombinasi Berbasis Whatsapp Pada Kelas Karyawan Prodi Teknik Informatika Universitas PGRI Madiun. Jurnal Nasional Pendidikan Teknik Informatika. 8.1, 81-86.

Sugiyono. 2013. Metode Penelitian Kuantitatif, Kualitatif dan R\&D. Bandung: Alfabeta.

Zhafira, N. H., Ertika, Y. dan Chairiyaton. 2020. Persepsi Mahasiswa Terhadap Perkuliahan Daring sebagai Sarana Pembelajaran Selama Masa Karantina Covid-19. Jurnal Bisnis dan Kajian Strategi Manajemen 4 : 1, 37-45. 